\title{
Ticlopidine in Its Prodrug Form Is a Selective Inhibitor of Human NTPDase1
}

\author{
Joanna Lecka, ${ }^{1,2}$ Michel Fausther, ${ }^{1,2}$ Beat Künzli, ${ }^{3}$ and Jean Sévigny ${ }^{1,2}$ \\ ${ }^{1}$ Département de Microbiologie-Infectiologie et d'Immunologie, Faculté de Médecine, Université Laval, Québec, \\ QC, Canada G1V 0A6 \\ ${ }^{2}$ Centre de Recherche du CHU de Québec, 2705 Boulevard Laurier, Local T1-49, Québec, QC, Canada G1V 4 G2 \\ ${ }^{3}$ Department of Surgery, Klinikum Rechts der Isar, Technische Universität München, 81675 Munich, Germany
}

Correspondence should be addressed to Jean Sévigny; jean.sevigny@crchul.ulaval.ca

Received 12 May 2014; Accepted 21 July 2014; Published 11 August 2014

Academic Editor: Mireia Martín-Satué

Copyright (C) 2014 Joanna Lecka et al. This is an open access article distributed under the Creative Commons Attribution License, which permits unrestricted use, distribution, and reproduction in any medium, provided the original work is properly cited.

\begin{abstract}
Nucleoside triphosphate diphosphohydrolase-1 (NTPDase1), like other ectonucleotidases, controls extracellular nucleotide levels and consequently their (patho)physiological responses such as in thrombosis, inflammation, and cancer. Selective NTPDase1 inhibitors would therefore be very useful. We previously observed that ticlopidine in its prodrug form, which does not affect P2 receptor activity, inhibited the recombinant form of human NTPDasel $\left(K_{i}=14 \mu \mathrm{M}\right)$. Here we tested whether ticlopidine can be used as a selective inhibitor of NTPDasel. We confirmed that ticlopidine inhibits NTPDasel in different forms and in different assays. The ADPase activity of intact HUVEC as well as of COS-7 cells transfected with human NTPDasel was strongly inhibited by $100 \mu \mathrm{M}$ ticlopidine, 99 and $86 \%$, respectively. Ticlopidine $(100 \mu \mathrm{M})$ completely inhibited the ATPase activity of NTPDasel in situ as shown by enzyme histochemistry with human liver and pancreas sections. Ticlopidine also inhibited the activity of rat and mouse NTPDasel and of potato apyrase. At $100 \mu \mathrm{M}$ ticlopidine did not affect the activity of human NTPDase2, NTPDase3, and NTPDase8, nor of NPP1 and NPP3. Weak inhibition (10-20\%) of NTPDase3 and -8 was observed at $1 \mathrm{mM}$ ticlopidine. These results show that ticlopidine is a specific inhibitor of NTPDasel that can be used in enzymatic and histochemistry assays.
\end{abstract}

\section{Introduction}

Extracellular nucleotides are released during different processes including exocytosis (e.g., platelets), shear stress (e.g., red blood cells), cell activation (e.g., platelets, endothelial cells), and cell lysis $[1,2]$. Once released the effect of nucleotides is exerted via the activation of several specific receptors, namely, $\mathrm{P} 2 \mathrm{X} 1-7$ and $\mathrm{P} 2 \mathrm{Y}_{1,2,4,6,11-14}$, and perhaps also via cysLT1R, cysLT2R, and/or GPR17 [3, 4].

The action of nucleotides (ATP, ADP, UTP, and UDP) on $\mathrm{P} 2$ receptors is regulated by ectonucleotidases $[5,6]$. Nucleoside triphosphate diphosphohydrolase-1 (NTPDasel) is the main ectonucleotidase at the surfaces of vascular endothelial cells, blood cells, and smooth muscle cells $[7,8]$. NTPDasel is present all along the cell surface and it was also observed in caveolae, a specialized structure of the plasma membrane $[9,10]$. Similar to other ectonucleotidases, NTPDasel catabolizes extracellular nucleotides [11].
By controlling extracellular nucleotides' levels, NTPDase1 affects various biological processes such as haemostasis [12, $13]$, vascular smooth muscle cell contraction $[14,15]$, pain perception $[3,16]$, angiogenesis, vascular permeability $[17,18]$, airway epithelial transport [19], endocrine secretion [20], neurotransmission and neuromodulation [21], inflammation, and immune reactions [11, 22-25]. An imbalanced ATP/ADP hydrolysis ratio was observed in patients with coronary artery disease and abdominal aortic aneurysm $[26,27]$ where NTPDasel would be expected to be involved. The product of NTPDasel activity, AMP, can be further catabolized by ecto$5^{\prime}$-nucleotidase to adenosine, the agonist of P1 receptors [28]. Adenosine is also involved in various functions regulated by ATP and most often exerts an opposite effect to ATP such as in the regulation of the vascular tone, cell migration, proliferation, and differentiation [29]. NTPDasel inhibitors may therefore represent a valuable tool to potentiate various physiological actions of nucleotides and could also serve as 
potential drug candidates for the treatment of some diseases associated with functions of NTPDasel such as in cardiovascular $[11,22,27]$ and immune diseases $[23,30]$ and cancer $[31,32]$.

We previously observed that, by blocking endothelial cell NTPDasel activity, the thienopyridines ticlopidine (Tyklid) and clopidogrel (Plavix) impaired platelet aggregation [33]. While clopidogrel is solubilized poorly in polar solvents, ticlopidine is easier to solubilize, making it a more convenient candidate for inhibition assays. It is noteworthy that ticlopidine (Tyklid) and clopidogrel (Plavix) are widely prescribed after heart attacks. As prodrugs they must be metabolically activated to the forms that irreversibly block platelet P2 $\mathrm{Y}_{12}$ receptors $[34,35]$. Although ticlopidine cannot obviously be used in a long-term basis as a therapeutic agent to block NTPDasel in human (due to its catabolism by the liver to a $\mathrm{P}_{2} \mathrm{Y}_{12}$ antagonist) it can have several other advantages such as studying NTPDasel functions. As several NTPDases have distinct functions, specific NTPDase inhibitors would be greatly valuable. For example, while NTPDasel abrogates platelet aggregation and their recruitment in intact vessels via the hydrolysis of ADP, NTPDase2, by the hydrolysis of ATP to ADP, has the ability to facilitate platelet activation at sites of extravasation [7]. Indeed, while NTPDasel is expressed by vascular endothelial cells, in touch with blood components, NTPDase2 is expressed in the subendothelium of veins and in the adventitial cells of arteries [36] which are exposed to platelets only after blood vessel breakage. In this study, we demonstrate that ticlopidine in its prodrug form can be used as a selective NTPDasel inhibitor.

\section{Materials and Methods}

2.1. Materials. Aprotinin, nucleotides, apyrase grade VII, phenylmethanesulfonyl fluoride (PMSF), ticlopidine, and malachite green were purchased from Sigma-Aldrich (Oakville, ON, Canada). Tris was obtained from VWR (Montreal, QC, Canada). DMEM was obtained from Invitrogen (Burlington, ON, Canada). Fetal bovine serum (FBS) and antibioticsantimycotics solution were from Wisent (St-Bruno, QC, Canada). Formalin and acetone were obtained from Fisher Scientific (Ottawa, ON, Canada). OCT freezing medium was purchased from Tissue-Tek, Sakura Finetk (Torrance, CA).

2.2. Plasmids. The plasmids used in this study have all been described in published reports: human NTPDasel (GenBank accession number U87967) [37], human NTPDase2 (NM_203468) [38], human NTPDase3 (AF034840) [39], human NTPDase8 (AY430414) [40], mouse NTPDase1 (NM_009848) [12], rat NTPDasel (NM_022587) [41], human NPP1 (NM_006208) [42], and human NPP3 (NM_005021) [43].

2.3. Cell Transfection and Protein Preparation. COS-7 cells were transfected with an expression vector (pcDNA3) containing the cDNA encoding for each ectonucleotidase using Lipofectamine (Invritrogen) and harvested $72 \mathrm{~h}$ later, as previously described [33]. For the preparation of protein extracts, transfected cells were washed three times with Tris-saline buffer at $4^{\circ} \mathrm{C}$, collected by scraping in harvesting buffer (95 mM NaCl, 0.1 mM PMSF, and $45 \mathrm{mM}$ Tris, $\mathrm{pH} 7.5$ ), and washed twice by centrifugation $\left(300 \mathrm{~g}, 10 \mathrm{~min}, 4^{\circ} \mathrm{C}\right)$. The cells were then resuspended in the harvesting buffer supplemented with $10 \mu \mathrm{g} / \mathrm{mL}$ aprotinin to block proteinases and sonicated. Nucleus and large cellular debris were discarded by centrifugation $\left(300 \times \mathrm{g}, 10 \mathrm{~min}, 4^{\circ} \mathrm{C}\right)$ and the supernatant (thereafter called lysate) was aliquoted and stored at $-80^{\circ} \mathrm{C}$ until used. Protein concentration in the lysates was estimated by Bradford microplate assay using bovine serum albumin as a standard [44].

\subsection{Enzymatic Activity Assays}

2.4.1. NTPDases and Apyrase (EC 3.6.1.5.). Activity was measured as described previously [5] in $0.2 \mathrm{~mL}$ of incubation medium ( $5 \mathrm{mM} \mathrm{CaCl}_{2}$ and $80 \mathrm{mM}$ Tris, $\mathrm{pH} \mathrm{7.4)}$ or TrisRinger buffer (in mM, $120 \mathrm{NaCl}, 5 \mathrm{KCl}, 2.5 \mathrm{CaCl}_{2}, 1.2 \mathrm{MgSO}_{4}$, $25 \mathrm{NaHCO}_{3}, 5 \mathrm{mM}$ glucose, and 80 Tris, $\mathrm{pH} \mathrm{7.4)}$ at $37^{\circ} \mathrm{C}$ with or without ticlopidine. Ectonucleotidase lysates were added to the incubation mixture and preincubated at $37^{\circ} \mathrm{C}$ for $3 \mathrm{~min}$. The reaction was initiated by the addition of $100 \mu \mathrm{M}$ ATP or ADP for NTPDases, with or without ticlopidine $(100 \mu \mathrm{M}$ or $1 \mathrm{mM}$ ) and stopped after $15 \mathrm{~min}$ with $50 \mu \mathrm{L}$ malachite green reagent. The activity of either enzyme at the surface of intact Human Umbilical Vein Endothelial Cells (HUVEC, passage 2) or NTPDasel transfected cells was measured in 24 well plates with the buffers indicated above supplemented with $125 \mathrm{mM} \mathrm{NaCl}$. The reaction was initiated as above and stopped by transferring a $200 \mu \mathrm{L}$ aliquot of the reaction mixture to a tube containing $50 \mu \mathrm{L}$ malachite green reagent. The liberated inorganic phosphate $\left(\mathrm{P}_{\mathrm{i}}\right)$ was measured at $630 \mathrm{~nm}$ according to Baykov et al. [45]. The increase of phosphate concentration due to enzyme activity was calculated by subtracting the phosphate concentration of the control reaction mixture, where the substrate was added after the malachite green reagent, from that of the respective reaction mixture. All experiments were performed in triplicate. One unit of enzymatic activity corresponded to the release of $1 \mu \mathrm{mol}$ $\mathrm{Pi} / \mathrm{min} \cdot \mathrm{mg}$ of protein or $1 \mu \mathrm{mol} \mathrm{Pi} / \mathrm{min} /$ well at $37^{\circ} \mathrm{C}$ for protein extracts and intact cells, respectively. The lysates from nontransfected COS-7 cells exhibited less than 5\% of the ATP or ADP hydrolysis generated by lysates from COS-7 cells transfected with either NTPDases' expressing plasmid and as such the activity of the contaminating nucleotidases was considered negligible.

2.4.2. NPPs (EC 3.1.4.1). Activity assays of human NPP1 and human NPP3 were carried out with paranitrophenyl thymidine $5^{\prime}$-monophosphate (pNP-TMP) as the substrate [42]. pNP-TMP hydrolysis was carried out at $37^{\circ} \mathrm{C}$ in $0.2 \mathrm{~mL}$ of the following incubation mixture: in $\mathrm{mM}, 1 \mathrm{CaCl}_{2}, 130 \mathrm{NaCl}$, $5 \mathrm{KCl}$, and 50 Tris, $\mathrm{pH} 8.5$, with or without $100 \mu \mathrm{M}$ ticlopidine. Recombinant human NPP1 or human NPP3 cell lysates were added to the incubation mixture and were preincubated at $37^{\circ} \mathrm{C}$ for $3 \mathrm{~min}$. The reaction was initiated by the addition of the substrate pNP-TMP $(100 \mu \mathrm{M})$, with or without $100 \mu \mathrm{M}$ 
ticlopidine. The production of $p$-nitrophenol in the reaction medium was measured at $310 \mathrm{~nm}, 15 \mathrm{~min}$ after the initiation of the reaction. The protein extracts from nontransfected COS7 cells exhibited less than 5\% of the pNP-TMP hydrolysis obtained with lysates from either NPP1 or NPP3 transfected cells, and as such was considered negligible.

2.4.3. Enzyme Histochemistry Assays. For histochemical studies, $5 \mu \mathrm{m}$ sections of freshly dissected tissues were embedded in OCT freezing medium and snap-frozen in isopentane in dry ice and stored at $-80^{\circ} \mathrm{C}$ until use. Sections of $6 \mu \mathrm{m}$ were obtained and fixed in $10 \%$ phosphate-buffered formalin mixed with cold acetone as before [46]. Localization of ectonucleotidase activities was determined using the Wachstein/Meisel lead phosphate method [47]. Fixed slices were preincubated for $30 \mathrm{~min}$ at RT in $50 \mathrm{mM}$ Tris-maleate buffer, $\mathrm{pH} 7.4$, containing $2 \mathrm{mM} \mathrm{CaCl}_{2}, 250 \mathrm{mM}$ sucrose, and $2.5 \mathrm{mM}$ levamisole as an inhibitor of alkaline phosphatases. Enzymatic reaction was performed for $1 \mathrm{~h}$ at $37^{\circ} \mathrm{C}$ in the same buffer supplemented with $5 \mathrm{mM} \mathrm{MnCl}_{2}$ to inhibit intracellular staining [48], $2 \mathrm{mM} \mathrm{Pb}\left(\mathrm{NO}_{3}\right)_{2}, 3 \%$ Dextran T-250 and in the presence of $200 \mu \mathrm{M}$ ATP with or without $100 \mu \mathrm{M}$ ticlopidine. For the control experiment, substrate was either omitted or added in the absence of divalent cations, which are essential for NTPDases' activity. The reaction was revealed by incubation with $1 \%\left(\mathrm{NH}_{4}\right)_{2} \mathrm{~S}$ v/v for exactly $1 \mathrm{~min}$. Samples were counterstained with aqueous haematoxylin, mounted with Mowiol mounting medium, and visualized and photographed with a BX51 Olympus microscope.

2.5. Statistic. Statistical analysis was done with the two-way ANOVA test. $P$ values below 0.05 were considered statistically significant.

\section{Results}

3.1. Influence of Ticlopidine on NTPDase Activity. We previously observed that ticlopidine inhibited recombinant human NTPDase1 [46]. In this work we verified if this compound can be used as a specific inhibitor of the enzyme. We first confirmed that ticlopidine was an inhibitor of NTPDasel from different sources. The ADPase activity of NTPDasel expressing cells, namely, intact COS-7 cells transfected with human NTPDasel or HUVEC, was strongly inhibited by $100 \mu \mathrm{M}$ ticlopidine, 99 and 75\% inhibition, respectively (Figure 1). ATPase activity was inhibited by about $25 \%$ in both cell types (Figure 1). The same ticlopidine concentration inhibited the ADPase activity of lysates from COS-7 cell transfected with an NTPDasel expression vector by about $58 \%$ (Figure 2(a)), while the ATPase activity was decreased more modestly than the ADPase activity by about $32 \%$, showing a similar tendency than what was observed for intact cells (Figures 1 and 2(a)). One $\mathrm{mM}$ ticlopidine further increased the inhibition of ADPase up to $73 \%$ and that of ATPase up to $64 \%$ (Figure 2(a)). At $100 \mu \mathrm{M}$ ticlopidine did not impair ATPase or ADPase activities of lysates from COS-7 cells transfected with NTPDase2, NTPDase-3, or NTPDase-8 (Figures 2(b)-2(d)). At $1 \mathrm{mM}$ concentration, ticlopidine inhibited only weakly the

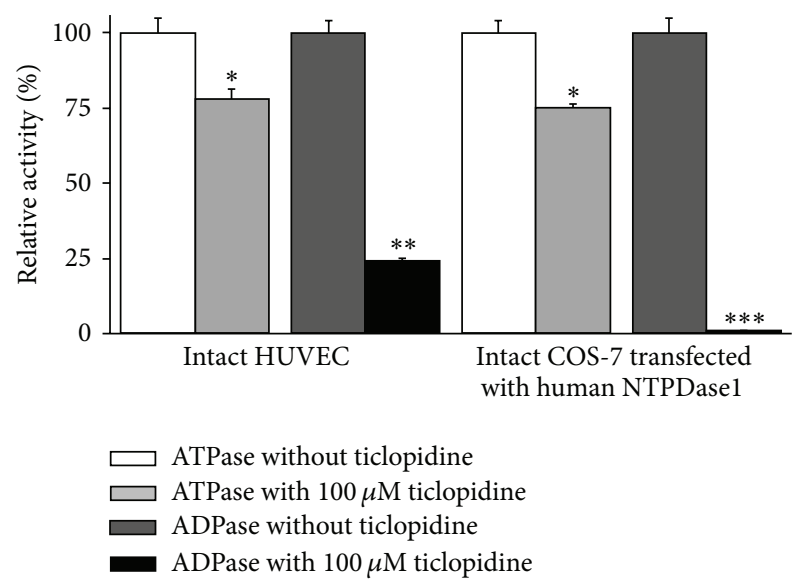

FIGURE 1: Influence of ticlopidine on intact HUVEC and COS-7 cells transfected with an expression vector encoding human NTPDasel. The substrate (ATP or ADP) was added together with ticlopidine, both at $100 \mu \mathrm{M}$. Relative activities are expressed as the mean \pm SD of 3 independent experiments with confluent cells (HUVEC from three different donors at passage 2), each performed in triplicate; mean cell number in one well was in the order of 250,000 . The activity (without ticlopidine, which was set at $100 \%$ ) with the substrate ATP corresponded to $2.5 \pm 0.12$ and $16.7 \pm 0.8 \mathrm{nmol} \mathrm{P} \cdot \mathrm{min}^{-1} \cdot \mathrm{well}^{-1}$ for HUVEC and transfected COS-7 cells, respectively, and with ADP to $3.5 \pm 0.17$ and $9.1 \pm 0.45 \mathrm{nmol} \mathrm{P}_{\mathrm{i}} \cdot \mathrm{min}^{-1} \cdot \mathrm{well}^{-1}$ for HUVEC and transfected COS-7, respectively. Data are presented as the mean \pm SD of 3 experiments carried out in triplicate. ${ }^{*} P=0.04 ;{ }^{* *} P=0.0003$; ${ }^{* * *} P=0.0001$.

ADPase activity (32\%) of NTPDase3 as well as its ATPase activity (14\%, Figure 2(c)) and the ATPase activity (19\%) of NTPDase8 (Figure 2(d)).

3.2. Influence of Ticlopidine on Murine NTPDasel Activity. We next investigated whether ticlopidine could also inhibit NTPDasel from other species. At $100 \mu \mathrm{M}$, ticlopidine inhibited the ATPase activity of both, mouse and rat NTPDasel, 23 and $36 \%$, respectively (Figure 3 ), and ADPase activity by about 30 and $41 \%$, respectively. The inhibition level was similar for all tested species at $1 \mathrm{mM}$ ticlopidine, about $60-70 \%$ of ATPase and $~ 75 \%$ of ADPase activity (Figures 2(a) and 3).

3.3. Influence of Ticlopidine on Other Ectonucleotidases. In our previous work we observed that $60 \mu \mathrm{M}$ ticlopidine, the calculated concentration of the compound after its administration to human patient [46], slightly inhibited rat ecto- $5^{\prime}$ nucleotidase but not human ecto- $5^{\prime}$-nucleotidase. Here we tested the effect of ticlopidine on other ectonucleotidases, including NTPDase from plant that is commercially available and widely used, namely, potato apyrase. The ADPase activity of this plant NTPDasel was also slightly more affected than its ATPase activity; the inhibition of ADPase activity by ticlopidine was 80 and $98 \%$ at $100 \mu \mathrm{M}$ and $1 \mathrm{mM}$ ticlopidine, respectively, and its ATPase activity, 75 and $95 \%$ for $100 \mu \mathrm{M}$ and $1 \mathrm{mM}$ ticlopidine, respectively (Figure $4(\mathrm{a})$ ).

There are also 2 other ectonucleotidases, NPPs, that efficiently hydrolyse ATP and ADP: NPP1 and NPP3. For these 


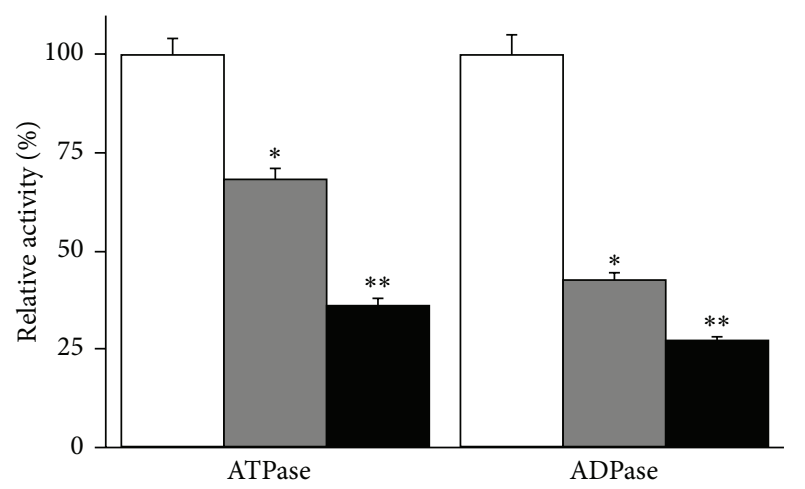

Without ticlopidine With $100 \mu \mathrm{M}$ ticlopidine With $1 \mathrm{mM}$ ticlopidine

(a) Human NTPDasel

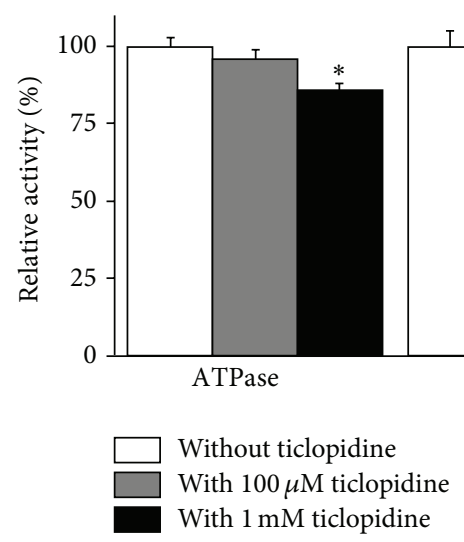

(c) Human NTPDase3

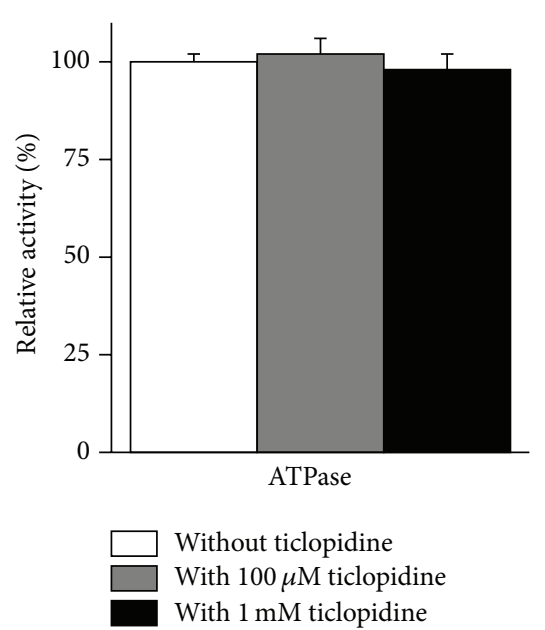

(b) Human NTPDase2

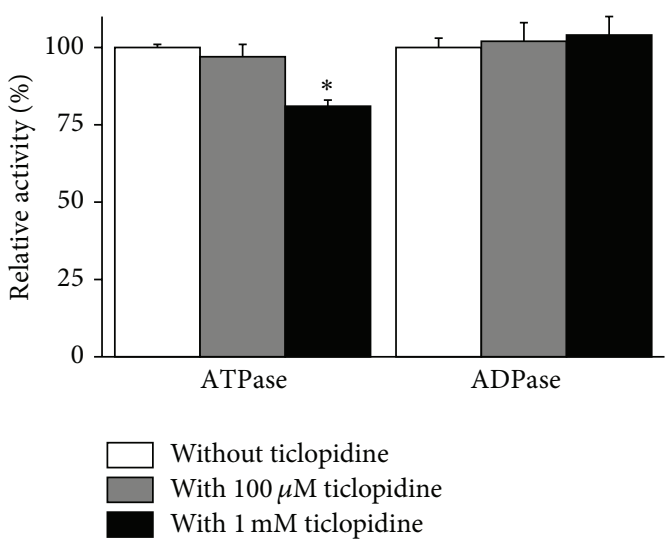

(d) Human NTPDase8

FIGURE 2: Influence of ticlopidine on recombinant human NTPDase activities. Enzymatic assays were carried out with lysates from COS7 cells transfected with an expression vector encoding the indicated enzyme. The substrate (ATP or ADP at the concentration of $100 \mu \mathrm{M}$ ) was added alone or together with ticlopidine at the concentration of either $100 \mu \mathrm{M}$ or $1 \mathrm{mM}$. The $100 \%$ activity in the absence of ticlopidine corresponded to the following: for human NTPDasel to $670 \pm 29$ and $550 \pm 21 \mathrm{nmol} \mathrm{P}_{\mathrm{i}} \cdot \mathrm{min}^{-1} \cdot \mathrm{mg} \mathrm{protein}^{-1}$ for ATP and ADP as substrates, respectively (a), for human NTPDase 2 to $1023 \pm 58 \mathrm{nmol} \mathrm{P}_{\mathrm{i}} \cdot \mathrm{min}^{-1} \cdot \mathrm{mg}$ protein ${ }^{-1}$ for ATP as substrate (b), for human NTPDase 3 to $256 \pm 37$ and $103 \pm 10 \mathrm{nmol} \mathrm{P} \cdot \mathrm{min}^{-1} \cdot \mathrm{mg}$ protein ${ }^{-1}$ for ATP and ADP as substrates, respectively (c), and for human NTPDase 8 to $148 \pm 16$ and $33 \pm 6 \mathrm{nmol}$ $\mathrm{P}_{\mathrm{i}} \cdot \mathrm{min}^{-1} \cdot \mathrm{mg}$ protein ${ }^{-1}$ for ATP and ADP as substrates, respectively (d). Data are presented as the mean \pm SD of 3 experiments carried out in triplicate. ${ }^{*} P=0.018 ;{ }^{* *} P=0.0002$.

enzymes we used the synthetic substrate pNP-TMP in our assay. Ticlopidine $(100 \mu \mathrm{M})$ did not affect the activity of either enzyme (Figure 4(b)). As the NPP activity was tested at a $\mathrm{pH}$ (slightly alkaline) that decreases the solubility of ticlopidine, we did not test higher concentrations of ticlopidine.

\subsection{Ticlopidine Inhibits NTPDase1 Activity in Human Tissues.} We then tested whether ticlopidine can also inhibit NTPDasel in situ. Enzyme histochemistry assays were performed with liver and pancreas tissue sections where NTPDasel is highly expressed in blood vessels (arteries, veins, capillaries, and sinusoids) as well as in the exocrine cells of the pancreas. Here we have used $200 \mu \mathrm{M}$ of ATP and $100 \mu \mathrm{M}$ ticlopidine. Under these conditions ticlopidine abolished the ATPase activity of NTPDasel (Figure 5). The inhibition observed was even more potent than in assays with cell lysates, similar to what we measured with the experiments with intact cells (Figures 1, 2(a), and 5).

\section{Discussion}

By regulating extracellular nucleotide levels, NTPDase1 affects haemostasis $[12,13,37]$, leukocyte migration $[24,25]$, immune responses $[6,49]$, angiogenesis, vascular permeability $[17,50]$, and vasoconstriction $[8,15]$. Therefore the identification of selective NTPDasel inhibitors would be valuable tools to study the function and pathological consequence of dysregulation of NTPDasel activity. Additionally, changes in ATP and ADP levels, potent ecto- 5 ' -nucleotidase inhibitors, change the level of adenosine and modulate the physiological responses of $\mathrm{P} 1$ receptor activation for which adenosine is the agonist $[33,51]$. 


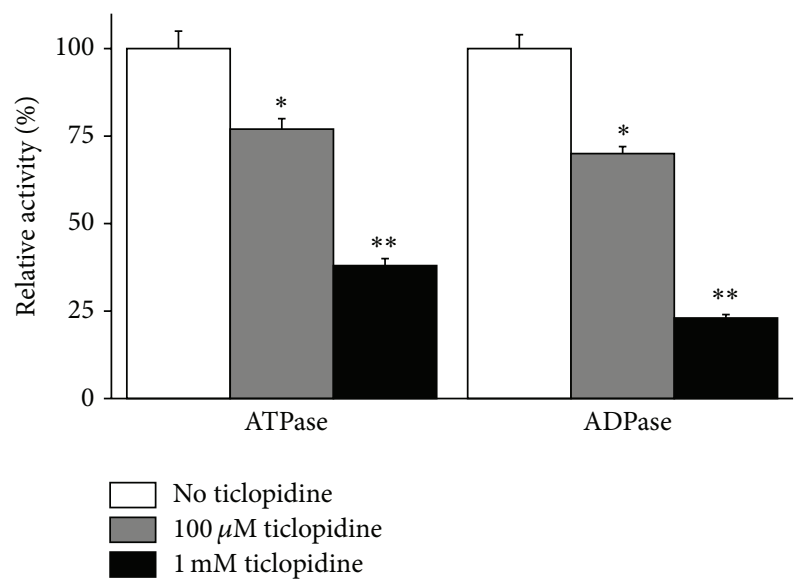

(a) Mouse NTPDasel

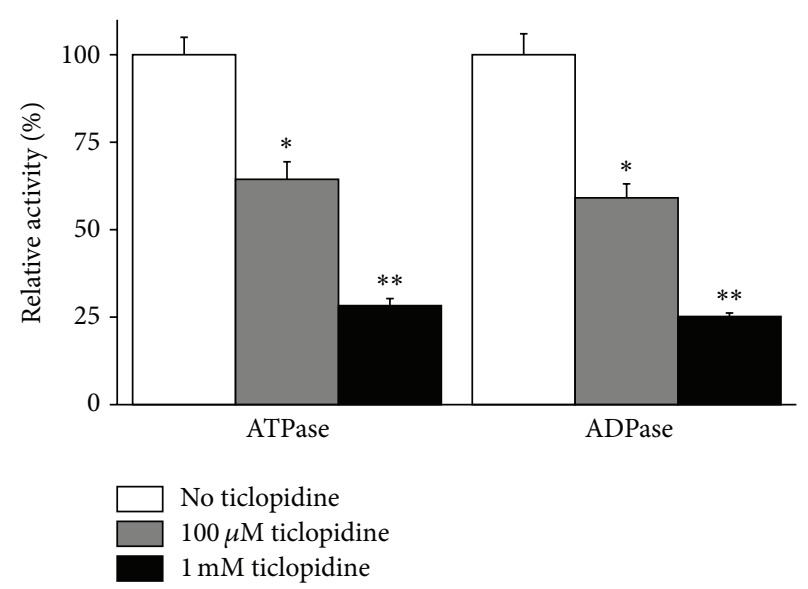

(b) Rat NTPDasel

FIGURE 3: Comparative effect of ticlopidine on recombinant murine NTPDasel. ATPase and ADPase activity of mouse (a) or rat (b) NTPDase1 without and with either $100 \mu \mathrm{M}$ or $1 \mathrm{mM}$ ticlopidine are presented. The $100 \%$ activity with ATP as the substrate in the absence of ticlopidine was $2781 \pm 136$ and $1502 \pm 66 \mathrm{nmol} \mathrm{P} \cdot \mathrm{min}^{-1} \cdot \mathrm{mg} \mathrm{protein}^{-1}$ for mouse and rat NTPDasel, respectively, and with ADP $2219 \pm 105 \mathrm{and} 1103 \pm 56 \mathrm{nmol}$ $\mathrm{P}_{\mathrm{i}} \cdot \mathrm{min}^{-1} \cdot \mathrm{mg}$ protein ${ }^{-1}$ for mouse and rat NTPDasel, respectively. Data are presented as the mean \pm SD of 3 experiments carried out in triplicate. ${ }^{*} P=0.0049 ;{ }^{* *} P=0.0007$.

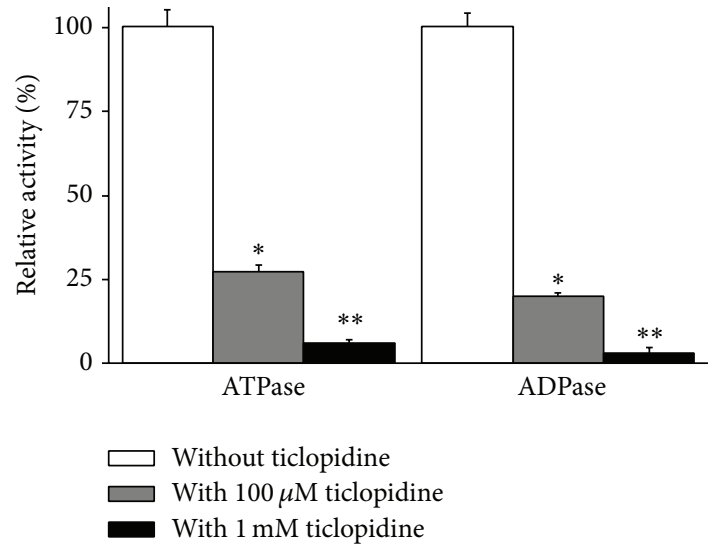

(a) Apyrase

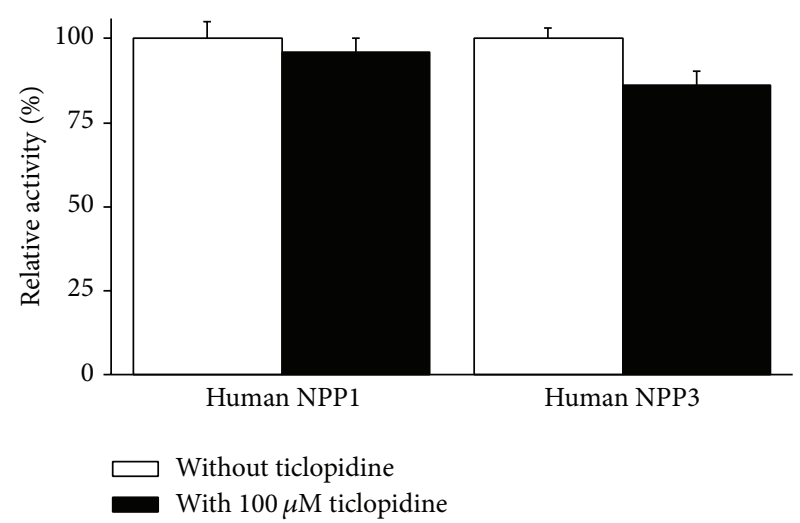

(b) Human NPPs

FIGURE 4: Influence of ticlopidine $(100 \mu \mathrm{M}$ or $1 \mathrm{mM})$ on the ATPase and ADPase activity of apyrase (a) and (100 $\mu \mathrm{M})$ on human NPP1 and human NPP3 (b). The activity of apyrase without ticlopidine was $159 \pm 7$ and $87 \pm 4 \mu \mathrm{moles} \mathrm{Pi} / \mathrm{min} \cdot \mathrm{mg}$ protein for ATP and ADP, respectively. Data are presented as the mean \pm SD of 3 experiments carried out in triplicate. The $100 \%$ activities without ticlopidine with pNP-TMP as the substrate were $71 \pm 3$ and $17 \pm 1 \mathrm{nmol} p$-nitrophenol $/ \mathrm{min} \cdot \mathrm{mg}$ protein for NPP1 and NPP3, respectively. ${ }^{*} P=0.0045 ;{ }^{* *} P=0.0002$.

Some inhibitors of NTPDasel have been described and characterized. Unfortunately most of them are not specific as they also inhibit other ectonucleotidases or affect purinoceptor activity. $N^{6}, N^{6}$-diethyl-D- $\beta$ - $\gamma$-dibromomethylene-ATP, also named ARL 67156, was found to be a weak and nonselective NPP1, NTPDasel, and NTPDase3 inhibitor $[52,53]$. Polyoxometalate (POM-1) inhibits NTPDasel but its action is limited by off-target actions on synaptic transmission [53, 54]. 1-amino-2-sulfo-4-(2-naphthylamino) anthraquinone was shown as a potent inhibitor of NTPDase1 but it inhibited at a similar level NTPDase3 [55]; suramin and sulfonate dyes such as reactive blue and pyridoxal phosphate6-azophenyl-2' $4^{\prime}$-disulfonic acid (PPADS) are also nonspecific inhibitors of NTPDasel activity [31, 56-59]. Recently we have synthesized and characterized potent and selective inhibitors of NTPDasel that are analogues of adenine nucleotides, namely, 8-BuS-ADP and 8-BuS-AMP [46]. Here we report that ticlopidine is also a potent and selective inhibitor of NTPDasel and as such can be used as a tool to study this ectonucleotidase function and pathophysiological consequences of abnormal activity. Ticlopidine is routinely administered to patients as a part of an antithrombotic therapy [60], but before it is activated by the liver it does not activate nor antagonize P2 receptors [61]. In a previous work we showed that thienopyridines, in their respective prodrug forms, prevent NTPDasel antiplatelet activity, due to the inhibition of its ADPase activity [33]. $100 \mu \mathrm{M}$ ticlopidine inhibited the hydrolysis of ADP by about $80 \%$ [33]. Kinetic assays 
No ATP
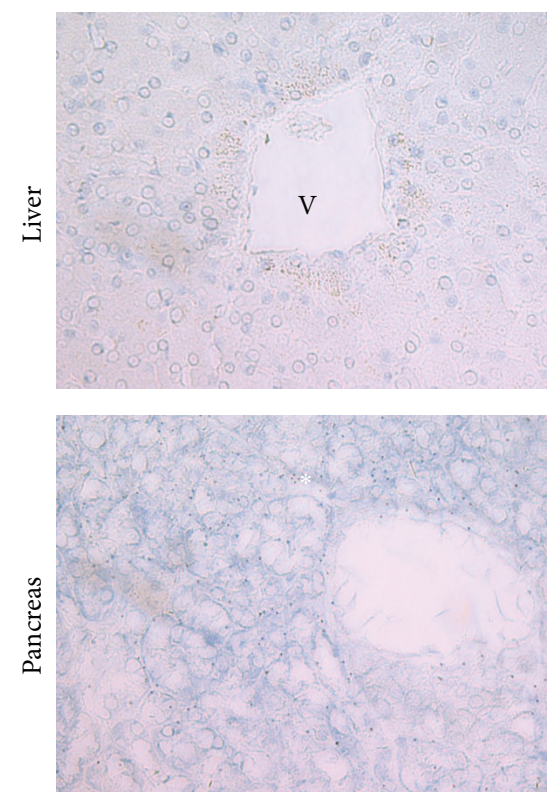

ATP
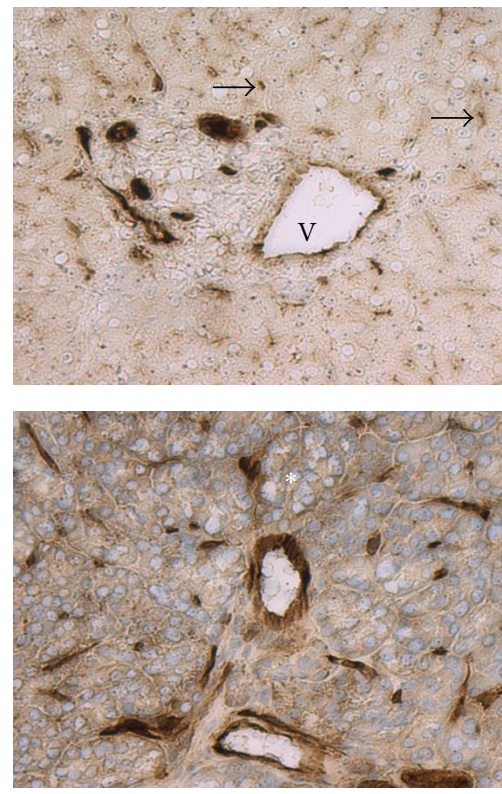

ATP + ticlopidine
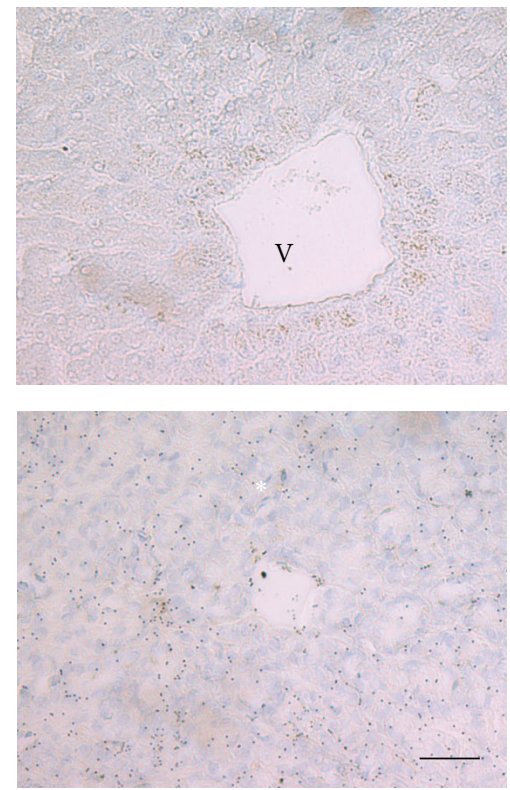

FIGURE 5: Inhibition of NTPDasel ATPase activity in human tissues by ticlopidine. Enzyme histochemistry was performed on serial sections with the substrate ATP at a final concentration of $200 \mu \mathrm{M}$ in the presence or absence of $100 \mu \mathrm{M}$ ticlopidine. In both tissues (liver and pancreas) NTPDasel ATPase activity is located in endothelial cells of all blood vessels including capillaries and sinusoids as well as in smooth muscle cells of arteries and in resident macrophages (Küpffer cells in the liver). In addition, in the pancreas NTPDasel is also expressed at the luminal surface of acinar cells and in zymogen granules. The ATPase activity is seen as a brown precipitate and is completely absent in presence of ticlopidine. Nuclei were counterstained with haematoxylin. Scale bar $=50 \mu \mathrm{m}$. V = vein; $*$ = Langerhans islet; arrows = Küpffer cells.

of the recombinant NTPDasel showed a mixed type inhibition by ticlopidine with a $K_{\text {iapp }}$ of 14 [33]. Here we further showed that ticlopidine can be used as a specific inhibitor of NTPDasel from various species, human, mouse, and rat (Figures 2(a) and 3). At $100 \mu \mathrm{M}$ concentration, ticlopidine inhibited the murine forms of NTPDasel less efficiently than human NTPDasel, but at $1 \mathrm{mM}$ we observed the same level of inhibition for all tested species (Figures 2(a) and 3). The most important value of this molecule is its selectivity in its prodrug form. Indeed at $100 \mu \mathrm{M}$, ticlopidine did not affect the activity of the other major ectonucleotidases, namely, NTPDase2, NTPDase3, NTPDase8, NPP1, and NPP3 (Figures $2(\mathrm{~b})-2(\mathrm{~d})$ and 4 ), whereas at $1 \mathrm{mM}$, ticlopidine weakly impeded the activities of NTPDase 3 and the ATPase of NTPDase8 (10-20\% inhibition, Figures 2(c) and 2(d)). In our previous study, we saw that ticlopidine had no effects on the human ecto- $5^{\prime}$-nucleotidase activity and decreased the activity of rat ecto- $5^{\prime}$-nucleotidase by about $25 \%$ at the concentration of $300 \mu \mathrm{M}$ [33].

An interesting aspect in the actual study was the observation that the inhibition of NTPDasel was more striking with a near complete inhibition when the enzyme was tested in its intact natural form, at the surface of cells such as in HUVEC or in tissues compared to the recombinant enzyme from a cell lysate (Figures 1 and 5). This characteristic, which needs to be further investigated, makes ticlopidine a good candidate for inhibition assays with cells that express NTPDasel.

In summary, we identified ticlopidine as a new specific inhibitor of NTPDasel that is specifically efficient with cell expressed NTPDasel.

\section{Conflict of Interests}

The authors declare that there is no conflict of interests regarding the publication of this paper.

\section{Acknowledgments}

This work was supported by a joint grant from The Canadian Hypertension Society and Pfizer and by grants from the Heart \& Stroke Foundation (HSF) of Quebec and from the Canadian Institutes of Health Research (CIHR) to Jean Sévigny. Jean Sévigny was also a recipient of a "Chercheur National" award from the Fonds de Recherche du QuébecSanté (FRQS). The authors thank Dr. Manjit Singh Rana for editing this paper.

\section{References}

[1] H. L. Goldsmith, D. N. Bell, S. Braovac, A. Steinberg, and F. McIntosh, "Physical and chemical effects of red cells in the shear-induced aggregation of human platelets," Biophysical Journal, vol. 69, no. 4, pp. 1584-1595, 1995.

[2] C. N. Morrell, "Regulation of platelet granule exocytosis by Snitrosylation," Proceedings of the National Academy of Sciences of the United States of America, vol. 102, no. 10, pp. 3782-3787, 2005.

[3] G. Burnstock, "Purinergic signalling," British Journal of Pharmacology, vol. 147, supplement 1, pp. S172-S181, 2006.

[4] P. Ciana, M. Fumagalli, M. L. Trincavelli et al., "The orphan receptor GPR17 identified as a new dual uracil nucleotides/ 
cysteinyl-leukotrienes receptor," EMBO Journal, vol. 25, no. 19, pp. 4615-4627, 2006.

[5] F. Kukulski, S. A. Lévesque, É. G. Lavoie et al., "Comparative hydrolysis of P2 receptor agonists by NTPDases 1, 2, 3 and 8," Purinergic Signalling, vol. 1, no. 2, pp. 193-204, 2005.

[6] F. Kukulski, S. A. Lévesque, and J. Sévigny, "Impact of ectoenzymes on $\mathrm{P} 2$ and $\mathrm{P} 1$ receptor signaling," Advances in Pharmacology, vol. 61, pp. 263-299, 2011.

[7] J. Sévigny, C. Sundberg, N. Braun et al., "Differential catalytic properties and vascular topography of murine nucleoside triphosphate diphosphohydrolase 1 (NTPDasel) and NTPDase2 have implications for thromboregulation," Blood, vol. 99, no. 8, pp. 2801-2809, 2002.

[8] G. Kauffenstein, A. Drouin, N. Thorin-Trescases et al., "NTPDasel (CD39) controls nucleotide-dependent vasoconstriction in mouse," Cardiovascular Research, vol. 85, no. 1, pp. 204-213, 2010.

[9] A. Kittel, E. Kaczmarek, J. Sevigny, K. Lengyel, E. Csizmadia, and S. C. Robson, "CD39 as a caveolar-associated ectonucleotidase," Biochemical and Biophysical Research Communications, vol. 262, no. 3, pp. 596-599, 1999.

[10] K. Koziak, E. Kaczmarek, A. Kittel et al., "Palmitoylation targets CD39/endothelial ATP diphosphohydrolase to caveolae," The Journal of Biological Chemistry, vol. 275, no. 3, pp. 2057-2062, 2000.

[11] S. C. Robson, J. Sévigny, and H. Zimmermann, “The ENTPDase family of ectonucleotidases: structure function relationships and pathophysiological significance," Purinergic Signalling, vol. 2, no. 2, pp. 409-430, 2006.

[12] K. Enjyoji, J. Sévigny, Y. Lin et al., "Targeted disruption of cd39/ATP diphosphohydrolase results in disordered hemostasis and thromboregulation," Nature Medicine, vol. 5, no. 9, pp. 1010$1017,1999$.

[13] A. J. Marcus, L. B. Safier, K. A. Hajjar et al., "Inhibition of platelet function by an aspirin-insensitive endothelial cell ADPase: thromboregulation by endothelial cells," Journal of Clinical Investigation, vol. 88, no. 5, pp. 1690-1696, 1991.

[14] G. Kauffenstein, C. R. Fürstenau, P. D'Orléans-Juste, and J. Sévigny, "The ecto-nucleotidase NTPDasel differentially regulates P2Y1 and P2Y2 receptor-dependent vasorelaxation," British Journal of Pharmacology, vol. 159, no. 3, pp. 576-585, 2010.

[15] L. Li, Z. Jia, C. Chen et al., "Physiological significance of P2X receptor-mediated vasoconstriction in five different types of arteries in rats," Purinergic Signalling, vol. 7, no. 2, pp. 221-229, 2011.

[16] M. J. Zylka, "Pain-relieving prospects for adenosine receptors and ectonucleotidases," Trends in Molecular Medicine, vol. 17, no. 4, pp. 188-196, 2011.

[17] O. Guckelberger, X. F. Sun, J. Sévigny et al., "Beneficial effects of CD39/ecto-nucleoside triphosphate diphosphohydrolase-1 in murine intestinal ischemia-reperfusion injury," Thrombosis \& Haemostasis, vol. 91, no. 3, pp. 576-586, 2004.

[18] G. G. Yegutkin, F. Marttila-Ichihara, M. Karikoski et al., "Altered purinergic signaling in CD73-deficient mice inhibits tumor progression," European Journal of Immunology, vol. 41, no. 5, pp. 1231-1241, 2011.

[19] M. Fausther, J. Pelletier, C. M. Ribeiro, J. Sévigny, and M. Picher, "Cystic fibrosis remodels the regulation of purinergic signaling by NTPDase1 (CD39) and NTPDase3," The American Journal of Physiology: Lung Cellular and Molecular Physiology, vol. 298, no. 6, pp. L804-L818, 2010.
[20] S. S. Stojilkovic and T. Koshimizu, "Signaling by extracellular nucleotides in anterior pituitary cells," Trends in Endocrinology and Metabolism, vol. 12, no. 5, pp. 218-225, 2001.

[21] G. Burnstock, "Physiology and pathophysiology of purinergic neurotransmission," Physiological Reviews, vol. 87, no. 2, pp. 659-797, 2007.

[22] B. Atkinson, K. Dwyer, K. Enjyoji, and S. C. Robson, "Ecto-nucleotidases of the CD39/NTPDase family modulate platelet activation and thrombus formation: potential as therapeutic targets," Blood Cells, Molecules, and Diseases, vol. 36, no. 2, pp. 217-222, 2006.

[23] G. Borsellino, M. Kleinewietfeld, D. Di Mitri et al., "Expression of ectonucleotidase CD39 by Foxp3+ Treg cells: hydrolysis of extracellular ATP and immune suppression," Blood, vol. 110, no. 4, pp. 1225-1232, 2007.

[24] R. Corriden, Y. Chen, Y. Inoue et al., "Ecto-nucleoside triphosphate diphosphohydrolase 1 (E-NTPDase1/CD39) regulates neutrophil chemotaxis by hydrolyzing released ATP to adenosine," The Journal of Biological Chemistry, vol. 283, no. 42, pp. 28480-28486, 2008.

[25] F. Kukulski, F. Bahrami, F. Ben Yebdri et al., "NTPDasel controls IL-8 production by human neutrophils," Journal of Immunology, vol. 187, no. 2, pp. 644-653, 2011.

[26] M. M. El-Omar, N. Islam, M. J. Broekman et al., "The ratio of ADP- to ATP-ectonucleotidase activity is reduced in patients with coronary artery disease," Thrombosis Research, vol. 116, no. 3, pp. 199-206, 2005.

[27] J. Lecka, E. Bloch-Boguslawska, S. Molski, and M. Komoszynski, "Extracellular purine metabolism in blood vessels (part II): activity of ecto-enzymes in blood vessels of patients with abdominal aortic aneurysm," Clinical and Applied Thrombosis/ Hemostasis, vol. 16, no. 6, pp. 650-657, 2010.

[28] H. Zimmermann, M. Zebisch, and N. Sträter, "Cellular function and molecular structure of ecto-nucleotidases," Purinergic Signalling, vol. 8, no. 3, pp. 437-502, 2012.

[29] P. Koszalka, B. Özüyaman, Y. Huo et al., "Targeted disruption of cd73/ecto- $5^{\prime}$-nucleotidase alters thromboregulation and augments vascular inflammatory response," Circulation Research, vol. 95, no. 8, pp. 814-821, 2004.

[30] H. Moncrieffe, K. Nistala, Y. Kamhieh et al., "High expression of the ectonucleotidase CD39 on T cells from the inflamed site identifies two distinct populations, one regulatory and one memory T cell population," Journal of Immunology, vol. 185, no. 1, pp. 134-143, 2010.

[31] C. E. Müller, J. Iqbal, Y. Baqi, H. Zimmermann, A. Röllich, and H. Stephan, "Polyoxometalates-a new class of potent ecto-nucleoside triphosphate diphosphohydrolase (NTPDase) inhibitors," Bioorganic and Medicinal Chemistry Letters, vol. 16, no. 23, pp. 5943-5947, 2006.

[32] M. Mandapathil, M. J. Szczepanski, M. Szajnik et al., "Increased ectonucleotidase expression and activity in regulatory T cells of patients with head and neck cancer," Clinical Cancer Research, vol. 15, no. 20, pp. 6348-6357, 2009.

[33] J. Lecka, M. S. Rana, and J. Sévigny, "Inhibition of vascular ectonucleotidase activities by the pro-drugs ticlopidine and clopidogrel favours platelet aggregation," British Journal of Pharmacology, vol. 161, no. 5, pp. 1150-1160, 2010.

[34] M. Cattaneo, "ADP receptors: inhibitory strategies for antiplatelet therapy," Timely Topics in Medicine: Cardiovascular Diseases, vol. 10, article E22, 2006. 
[35] O. Ö. Braun, S. Amisten, A. Wihlborg, K. Hunting, D. Nilsson, and D. Erlinge, "Residual platelet ADP reactivity after clopidogrel treatment is dependent on activation of both the unblocked $\mathrm{P} 2 \mathrm{Y} 1$ and the P2Y12 receptor and is correlated with protein expression of P2Y12," Purinergic Signalling, vol. 3, no. 3, pp. 195201, 2007.

[36] J. A. Dranoff, E. A. Kruglov, S. C. Robson, N. Braun, H. Zimmermann, and J. Sévigny, "The ecto-nucleoside triphosphate diphosphohydrolase NTPDase2/CD3911 is expressed in a novel functional compartment within the liver," Hepatology, vol. 36, no. 5, pp. 1135-1144, 2002.

[37] E. Kaczmarek, K. Koziak, J. Sévigny et al., "Identification and characterization of CD39/vascular ATP diphosphohydrolase," The Journal of Biological Chemistry, vol. 271, no. 51, pp. 3311633122, 1996.

[38] A. F. Knowles and W. Chiang, "Enzymatic and transcriptional regulation of human ecto-ATPase/E-NTPDase 2," Archives of Biochemistry and Biophysics, vol. 418, no. 2, pp. 217-227, 2003.

[39] T. M. Smith and T. L. Kirley, "Cloning, sequencing, and expression of a human brain ecto-apyrase related to both the ectoATPases and CD39 ecto-apyrases," Biochimica et Biophysica Acta: Protein Structure and Molecular Enzymology, vol. 1386, no. 1, pp. 65-78, 1998.

[40] F. Bigonnesse, S. A. Lévesque, F. Kukulski et al., "Cloning and characterization of mouse nucleoside triphosphate diphosphohydrolase-8," Biochemistry, vol. 43, no. 18, pp. 5511-5519, 2004.

[41] B. Kegel, N. Braun, P. Heine, C. R. Maliszewski, and H. Zimmermann, "An ecto-ATPase and an ecto-ATP diphosphohydrolase are expressed in rat brain," Neuropharmacology, vol. 36, no. 9, pp. 1189-1200, 1997.

[42] S. I. Belli and J. W. Goding, "Biochemical characterization of human PC-1, an enzyme possessing alkaline phosphodiesterase I and nucleotide pyrophosphatase activities," European Journal of Biochemistry, vol. 226, no. 2, pp. 433-443, 1994.

[43] P. Jin-Hua, J. W. Goding, H. Nakamura, and K. Sano, "Molecular cloning and chromosomal localization of PD-I $\beta$ (PDNP3), a new member of the human phosphodiesterase I genes," Genomics, vol. 45, no. 2, pp. 412-415, 1997.

[44] M. M. Bradford, "A rapid and sensitive method for the quantitation of microgram quantities of protein utilizing the principle of protein dye binding," Analytical Biochemistry, vol. 72, no. 1-2, pp. 248-254, 1976.

[45] A. A. Baykov, O. A. Evtushenko, and S. M. Avaeva, "A malachite green procedure for orthophosphate determination and its use in alkaline phosphatase-based enzyme immunoassay," Analytical Biochemistry, vol. 171, no. 2, pp. 266-270, 1988.

[46] J. Lecka, I. Gillerman, M. Fausther et al., "8-BuS-ATP derivatives as specific NTPDasel inhibitors," British Journal of Pharmacology, vol. 169, no. 1, pp. 179-196, 2013.

[47] N. Braun, J. Sévigny, S. K. Mishra et al., "Expression of the ectoATPase NTPDase 2 in the germinal zones of the developing and adult rat brain," European Journal of Neuroscience, vol. 17, no. 7, pp. 1355-1364, 2003.

[48] R. H. Dahl and J. N. Pratley, "The effects of magnesium on nucleoside phosphatase activity in frog skin," Journal of Cell Biology, vol. 33, no. 2, pp. 411-418, 1967.

[49] S. Deaglio and S. C. Robson, "Ectonucleotidases as regulators of purinergic signaling in thrombosis, inflammation, and immunity," Advances in Pharmacology, vol. 61, pp. 301-332, 2011.
[50] G. G. Yegutkin, M. Helenius, E. Kaczmarek et al., "Chronic hypoxia impairs extracellular nucleotide metabolism and barrier function in pulmonary artery vasa vasorum endothelial cells," Angiogenesis, vol. 14, no. 4, pp. 503-513, 2011.

[51] H. Zimmermann, " 5 -Nucleotidase: molecular structure and functional aspects," Biochemical Journal, vol. 285, no. 2, pp. 345365, 1992.

[52] B. E. Crack, C. E. Pollard, M. W. Beukers et al., "Pharmacological and biochemical analysis of FPL 67156, a novel, selective inhibitor of ecto-ATPase," British Journal of Pharmacology, vol. 114, no. 2, pp. 475-481, 1995.

[53] S. A. Lévesque, É. G. Lavoie, J. Lecka, F. Bigonnesse, and J. Sévigny, "Specificity of the ecto-ATPase inhibitor ARL 67156 on human and mouse ectonucleotidases," British Journal of Pharmacology, vol. 152, no. 1, pp. 141-150, 2007.

[54] M. J. Wall, J. Chen, S. Meegalla et al., "Synthesis and evaluation of novel 3,4,6-substituted 2-quinolones as FMS kinase inhibitors," Bioorganic \& Medicinal Chemistry Letters, vol. 18, no. 6, pp. 2097-2102, 2008.

[55] Y. Baqi, K. Atzler, M. Köse, M. Glänzel, and C. E. Müller, "Highaffinity, non-nucleotide-derived competitive antagonists of platelet P2Y12 receptors," Journal of Medicinal Chemistry, vol. 52, no. 12, pp. 3784-3793, 2009.

[56] R. Bültmann, H. Wittenburg, B. Pause, G. Kurz, P. Nickel, and K. Starke, "P2-purinoceptor antagonists: III. Blockade of P2purinoceptor subtypes and ecto-nucleotidases by compounds related to suramin," Naunyn-Schmiedeberg's Archives of Pharmacology, vol. 354, no. 4, pp. 498-504, 1996.

[57] B. C. Chen, C. Lee, and W. Lin, "Inhibition of ecto-ATPase by PPADS, suramin and reactive blue in endothelial cells, C6 glioma cells and RAW 264.7 macrophages," British Journal of Pharmacology, vol. 119, no. 8, pp. 1628-1634, 1996.

[58] H. Wittenburg, R. Bültmann, B. Pause, C. Ganter, G. Kurz, and K. Starke, "P2-purinoceptor antagonists: II. Blockade of P2purinoceptor subtypes and ecto-nucleotidases by compounds related to Evans blue and trypan blue," Naunyn-Schmiedeberg's Archives of Pharmacology, vol. 354, no. 4, pp. 491-497, 1996.

[59] M. N. Munkonda, G. Kauffenstein, F. Kukulski et al., "Inhibition of human and mouse plasma membrane bound NTPDases by P2 receptor antagonists," Biochemical Pharmacology, vol. 74, no. 10, pp. 1524-1534, 2007.

[60] S. W. Lee, S. Park, M. Hong et al., "Triple versus dual antiplatelet therapy after coronary stenting: impact on stent thrombosis," Journal of the American College of Cardiology, vol. 46, no. 10, pp. 1833-1837, 2005.

[61] P. Savi and J. M. Herbert, "Clopidogrel and ticlopidine: P2Y 12 adenosine diphosphate-receptor antagonists for the prevention of atherothrombosis," Seminars in Thrombosis and Hemostasis, vol. 31, no. 2, pp. 174-183, 2005. 


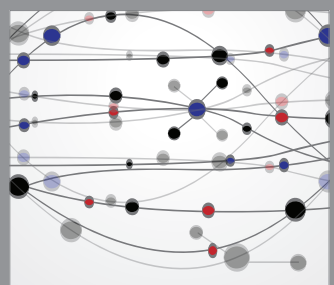

The Scientific World Journal
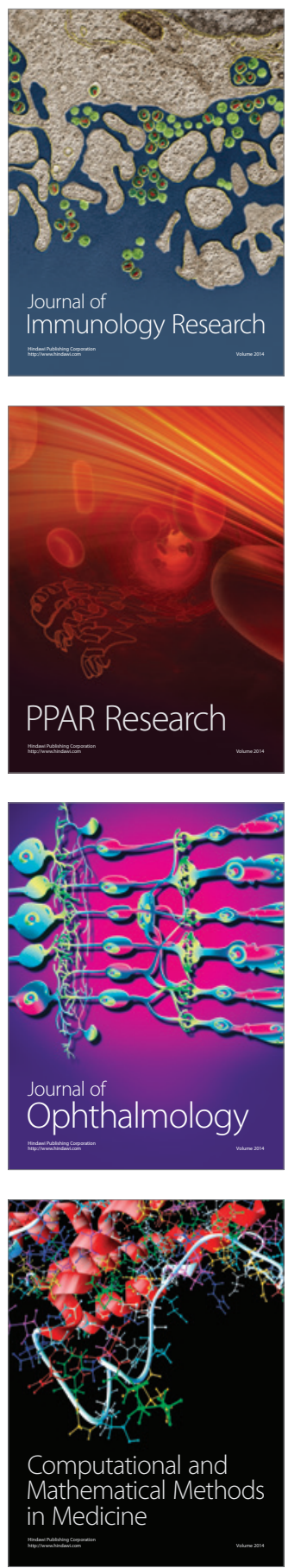

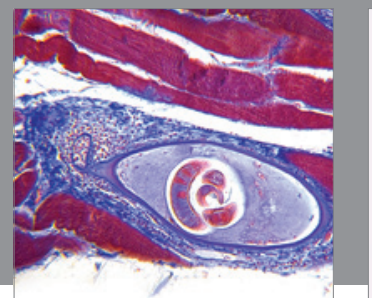

Gastroenterology

Research and Practice
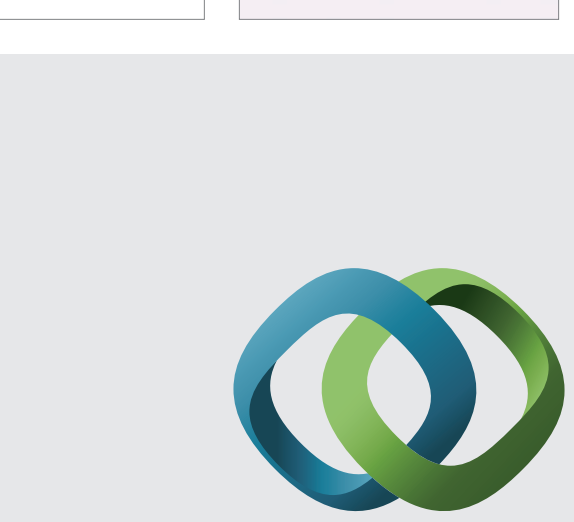

\section{Hindawi}

Submit your manuscripts at

http://www.hindawi.com
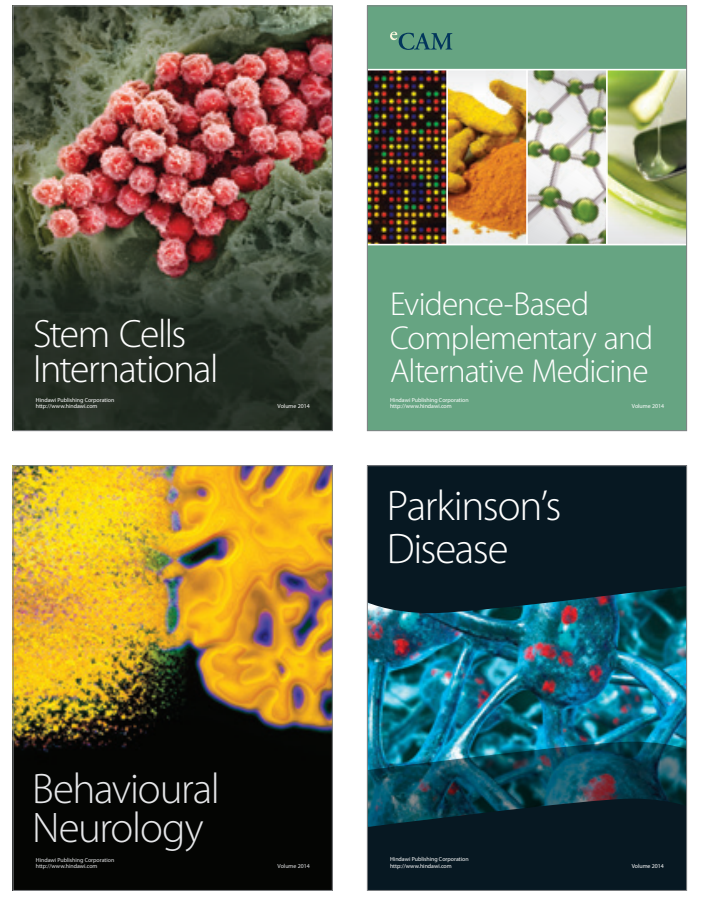
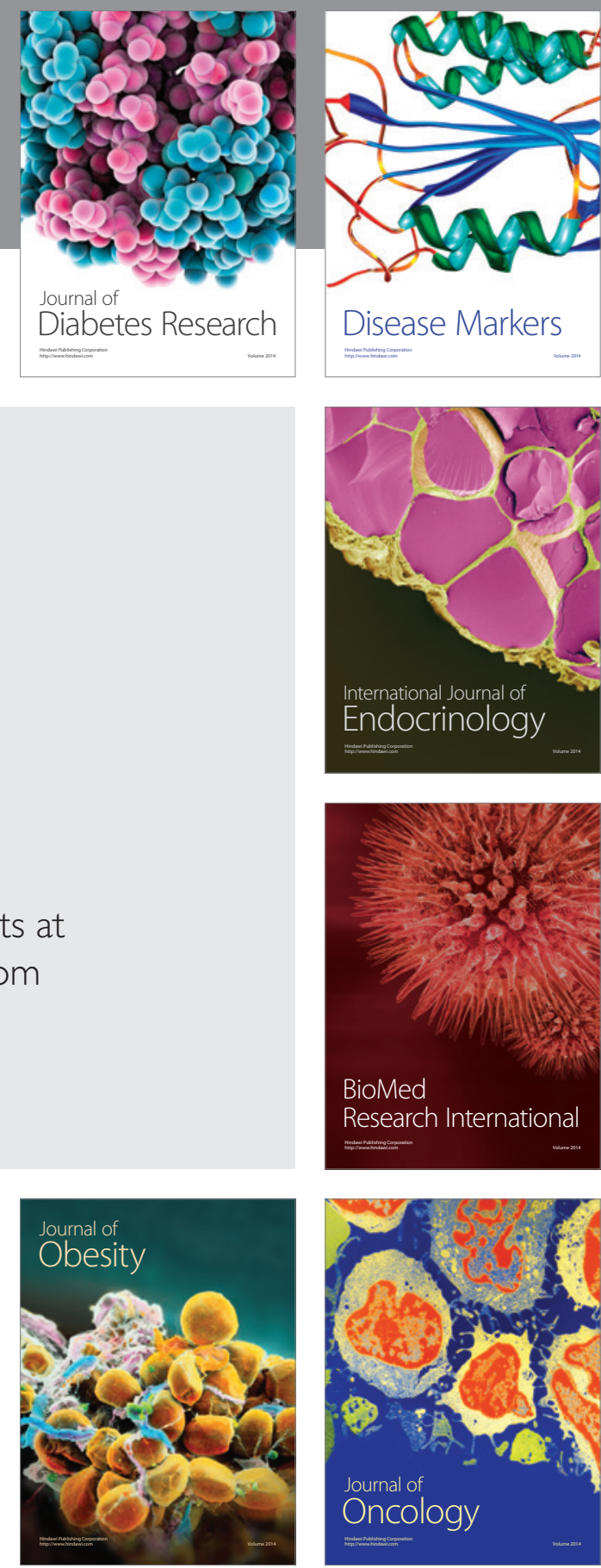

Disease Markers
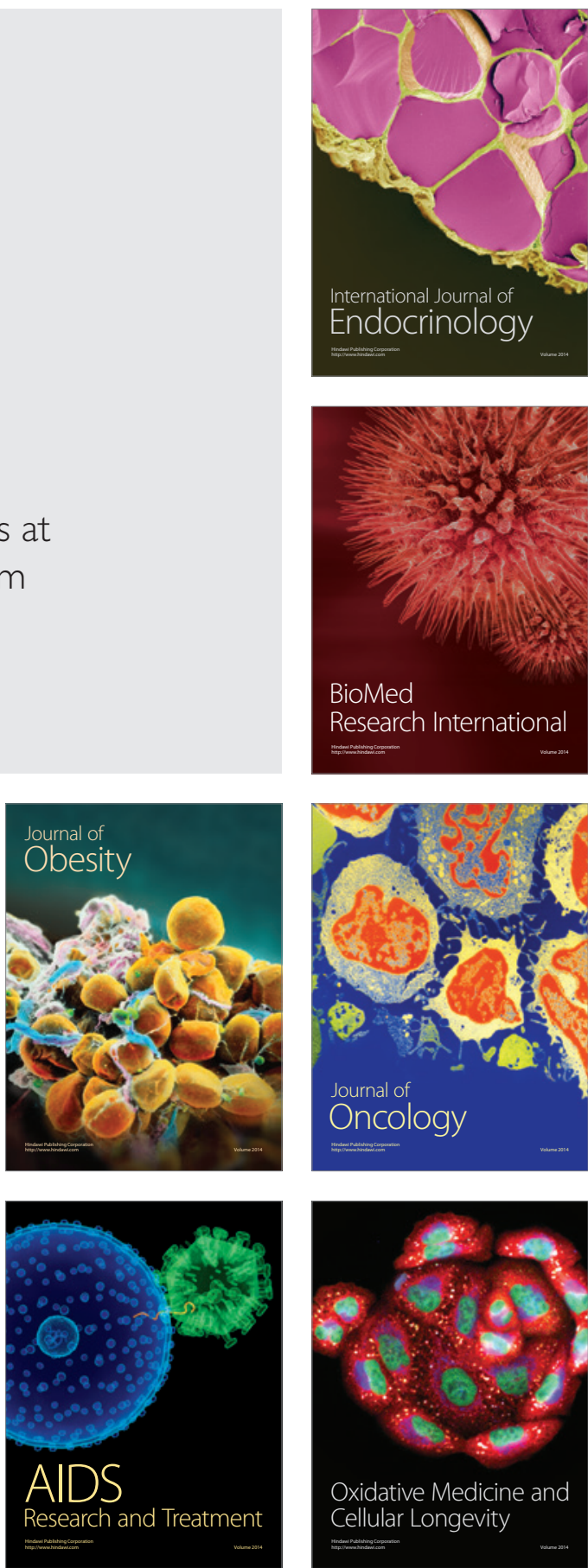